\title{
The Europeanisation of Employment Policy in the Czech Republic*
}

\author{
ANNE SCHUTTPELZ** \\ Centrum für Globalisierung und Governance \\ Department für Wirtschafts und Sozialwissenschaften \\ Universität Hamburg \\ Hamburg, Germany
}

\author{
Pregledni članak \\ UDK: 331.5(437.1) \\ Primljeno: ožujak 2006.
}

\begin{abstract}
Although the Euopean Employment Strategy (EES) has applied to the new Member States only after accession, it had shaped the Czech employment policy already well before that date. Therefore, the question arises, how the EES could gain such influence, despite the fact that the EES represents neither a very strong kind of EU regulation nor was pushed by the European Commission in course of its pre-accession strategy. Europeanisation theory suggests that basically institutional misfit between EU and national regulation as well as certain national conditions may explain the adaptation of national policies to EU norms.

However, as the EES represents a very soft type of EU regulation, the cognitive influence on dominant national actors plays an important role for its impact. In the Czech case, the EU has been quite successful in influencing the agenda setting for the employment - the interpretation of labour market problems was shaped by the aims of the EES and led to an activation and streamlining of the employment policy. However, it was less the official employment policy review as part of the pre-accssion strategy than the model function of the EES that was decesive for successful and early adaptation.
\end{abstract}

Key words: European Employment Strategy, Czech Republic, adaptation, EU accession.

\section{INTRODUCTION}

The European Employment Strategy (EES) arose from the recognition of a crisis in European social policies in the mid1990s and was framed as an alternative governance approach to sustain and diffuse the European social model (see Mosher and Trubek 2003.). The need for balancing economic integration by promoting social cohesion in the EU has always been discussed, especially when launching the

\footnotetext{
*An earlier version of this article was presented at the ESPAnet Conference 2005., September 22-24, 2005., University of Fribourg, Switzerland. I am grateful to Siniša Zrinščak and two anonymous reviewers for useful comments that helped much for revising the paper.

** Ana Schüttpelz, Centrum für Globalisierung und Governance Department für Wirtschafts und Sozialwissenschaften/Universität Hamburg, Allende-Platz 1, 20146 Hamburg/Germany, schuettpelz@soziallwiss. uni-hamburg.de
} 
Single Market. In the mid-1990s, however, two factors strengthened the demand for developing the social dimension of the integration project. On the one hand, it became obvious that the common, structural nature of the unemployment problems in the EU could not be adequately dealt with by simply promoting economic growth (as was still hoped in the 1988. Cecchini Reports). On the other hand, the monetary stabilisation policy pursued in the run-up to the Economic and Monetary Union (EMU) called for a more co-ordinated, employment-oriented policy response at the European level (see also Commission, 2002.). Following a functionalist approach to European integration it can be argued, that the EU's lack of competence and capacity for social policy became an obstacle to its economic activities. However, the question remains: How has the EES changed European employment policies?

During the last decade, Europeanisation research has developed as a new field within the study of European integration. The concept of Europeanisation has been used for answering the question of how European policies, norms and rules affect domestic structures and policies (for an overview see for instance Vink, 2003.; Radaelli, 2000.a; 2004.). ${ }^{1}$ In doing this, the Europeanisation literature has so far predominantly focused on the institutional dynamics of domestic adaptation processes, that is institutionalist approaches prevail.

The central explanation for Europeanisation is that, in principle, EU policies create an »adaptational pressure « which, however, differs across member states and policy areas. These differences have been mainly seen as the result of varying $»$ institutional misfit « between EU and member states (see for instance Börzel, 1999.; Green Cowles et al., 2000.; recently Börzel/ Risse, 2005). Recently, it has been argued that there are a number of cases that cannot be explained well by this »goodness of fit « logic. ${ }^{2}$

Knill and Lehmkuhl (1999.) were one of the first who differentiated various Europeanisation mechanisms, namely according to the types of integration policies. They propose that »institutional misfit « may explain best cases of positive integration processes, whereas negative integration affects national policies mainly via regulatory competition. In addition, so called »framing integration « works even more indirectly as it is above all about cognitive changes. This differentiation is one way to bring to the fore the hitherto underestimated role of political actors and actor constellations within the domestic adaptation processes to EU regulation. ${ }^{3}$

Based on a critical review of the Europeanisation literature, my main argument throughout this article is that effective Europeanisation for most types of EU policies, especially for all kinds of soft law, crucially depends on domestic actors and political structures. In principle, most EU policies (except directly applicable hard law) represent an input to the national policy-making processes. However, this input is clearly specified in terms of implementation or policy transfer from the EU to the national level. Different types of EU regulation include different types of implementation

\footnotetext{
${ }^{1}$ Practically, nearly all research in the field is dealing with the response of EU member states on requirements stemming from the EU level.

${ }^{2}$ This is also a conclusion of the first systematic study on Europeanisation in the area of employment and social affairs: Falkner et al. 2005. show that misfit doesn't explain the different implementation of labour directives in the Member States.

${ }^{3}$ For a critical assessment of the Europeanisation literature from the perspective of Political Sociology see Jacquot/ Woll 2003.
} 
mechanisms along a voluntary-coercive continuum. The more a EU regulation draws on voluntary elements, the more the adaptation to policies of this kind depends on the support of dominant domestic actors and political structures. One could say that the output of Europeanisation processes is less a question of »institutional misfit «, but more of »cognitive « and »structural « misfit. It is not so much the difference between the existing domestic and EU policies that makes for adaptation results, but the differences between the interests of domestic and EU political actors as well as the differences between domestic policy-making structures and the requirements stemming from an EU policy to be implemented. Therefore, Europeanisation processes may be best approached by means of an extended policy analysis, which explains the policy output (= adaptation to EU policy) as a result of decision-making in a specifically structured domestic policy area, and regards the respective EU policy as a specific input to these policy-making structures. This is even more so with the preparation processes for the EU accession, because the EU had no specific sanction possibilities within the framework of the pre-accession conditionality regime to press through certain policies in the future member States.

In this paper, the role of political actors in the Europeanisation process is demonstrated with the preparation for implementing the European Employment Strategy (EES) in the Czech Republic in the course of the accession to the EU. The EES is based on the so-called $\gg$ open method of co-ordination « (OMC) which comprises a voluntary adaptation of national policies by involvement in a multi-level process of benchmarking, multilateral surveillance, peer review, exchanges of information, co-operation and consultation. It favours the modification of governance structures, while leaving detailed policy decisions to the national authorities. So far, there is no research on the impact of the EES from an explicit Europeanisation perspective. However, it has been argued, that the impact of the EES (as a framing EU policy) on national decision-making has been rather low for old EU Member States (see Ardy/ Umbach, 2004.). As the specific accession situation in principle involves high pressure for comprehensive policy transfers from the EU (»conditionality«, see Grabbe 2002.), the effect on CEE employment policies might be different. The case of the Eastern enlargement is interesting from the Europeanisation perspective, because there is hardly any research on the impact of EU regulation on non-Member states. As Schimmelfennig and Sedelmeier (2002.) rightly stated, the EU enlargement is a highly under-researched area within European studies. However, the accession to the EU opened up a possibility to study a multitude of Europeanisation processes within a rather short time period, as the future Member States had to adopt to the whole set of rules, norms, institutional structures, ideas and meanings, interests and identities which are the result of previous European integration processes (see also Schimmelfennig and Sedelmeier, 2005.).

Therefore, the following analysis of the Czech case seeks to answer two main research questions: How did the Czech employment policy adapt to the EES during the pre-accession period? Which structural changes in the policy area (actor constellations and institutions relevant in the Czech employment policy) are connected to this adaptation process? The paper is structured as follows: First, I will reflect on the variance of Europeanisation mechanisms discussed in the literature, then introduce the European Employment Strategy, and in the main part focus on its impact on the Czech employment policy. Finally, I will draw some conclusions on the Europeanisation mechanisms in the pre-accession situation and their results. 


\section{EUROPEANISATION MECHANISMS}

The main subject of Europeanisation research regarding the question »what is changed? « is public policy, which should be distinguished analytically from studies on the Europeanisation of political structures (see Radaelli, 2000.a). However, there is an interaction between policy dynamics and political structures in the EU (see Héritier and Knill, 2000.; Radaelli, 2004.).

Concerning Europeanisation of public policies, different mechanisms of the process have been distinguished according to the type of regulation to be implemented. That is, the way in which the EU regulation is transferred varies between policies. In principle, these mechanisms lie along a continuum between a voluntary and a coercive dimension (like in the policy transfer approach developed by Dolowitz and Marsh 2000.), although there is no agreed concept in the Europeanisation research how to distinguish the different mechanisms. For instance, Knill and Lehmkuhl (1999.) distinguish between the concrete prescription of European institutional models (in the case of positive integration policies), altering the domestic opportunity structure (in the case of negative integration policies), and providing legitimate policy ideas to domestic actors (in the case of »framing « policies). In a paper on policy transfer, Radaelli (2000.b) presents the mechanisms of coercion, mimetism and normative pressures. In any case, mechanisms of Europeanisation range from very direct, coercive influences in cases where concrete and compulsory EU regulation exists, to very indirect influences (learning).

I argue here that the differences between the Europeanisation mechanisms are rooted in the way the EU and domestic political actors are involved into the respective implementation of EU policies. That is, according to the distribution of agency within the implementation process - which is basically prescribed by the kind of EU regulation to be transferred - EU actors may be more or less involved into the national adaptation processes.

So, the transfer process has a more voluntary character when domestic agency prevails (especially in cases of EU soft law, but also - to a lesser degree - with the transposition of EU directives), whereas it is more coercive when EU agency is decisive for implementation (in cases of directly applicable EU hard law). Therefore, it is important to consider the agency of the different actors involved in the transfer process in any analysis of Europeanisation. Of course, political actors are bound by the given structures of the decision making process. The policy output (adaptation of national policies to EU regulation) depends on the institutional framework, as well as on the actor constellations in the policy area. However, within this structural context, the concrete interaction of the political actors involved, that is the process of decision making, shapes the result of the Europeanisation process. Therefore, the changes in the employment policy of accession countries should be basically understood as an outcome of the interaction between different EU actors and domestic actors which have specific capabilities, resources and interests, and underlie specific constraints defined by the structures of the policy area. So, the policy changes are not only dependent on the institutional misfit/ the adaptive demand created by the EU regulation to be implemented, but also on the dominant actors within the Europeanisation process.

Therefore, it is argued here that Europeanisation processes may be approached best by means of an extended policy analysis, which explains the policy output as a result of domestic politics and decision-making processes. However, it has to be shown how exactly political actors deal with EU policies and the adaptation pressure they bring about. First, EU policies may influence the decision making at different stages of the political process. Second, EU policies may 
re- or devalue certain political actors and structures, which affect the behaviour of domestic actors in the decision-making. Revaluation means an extension of available resources for domestic actors who are in line with or can make use of the respective EU policy. Third, actors have belief systems, which guide their political behaviour and coalition building within the political process. These belief systems also affect the constellation of actors and may be altered or reinforced by EU adaptation pressure. Changing belief systems of actors are the most incremental way to change the course of political action and therefore for the $\mathrm{Eu}$ ropeanisation of domestic policies.

»Framing policies « - as they are called by Knill and Lemkuhl (1999.) - or EU soft law (which are the kind of policies dealt with in this paper) are basically characterised by providing European support to the national political actors or, in other words, by a generally high relevance of domestic agency for the adaptation process. Europeanisation in these cases works predominantly by providing domestic actors with additional legitimacy for reform models, by assisting in the development of solutions for domestic problems, or by altering the expectations and beliefs of domestic actors, which may finally facilitate decisionmaking. This has been called »cognitive Europeanisation«, a mechanism of shaping the perceptions and attitudes towards problems and policies (Radaelli, 2000.a) which has dominated the adaptation to EU social policy in the accession process.

\section{THE EUROPEAN EMPLOYMENT STRATEGY}

To overcome structural problems with the European integration of social policy (as analysed for instance by Scharpf, 1997.), the EES - developed in the late 1990s - was based on a rather flexible and participatory approach that reflects a shift away from the EU traditional top-down governance (see Goetschy, 1999; M Mosher and Trubek, 2003.). This is the so-called »open method of co-ordination « (OMC), a procedure first developed to ensure a certain degree of convergence of economic policies among the Member States in the run-up to the European Monetary Union. The OMC comprises a voluntary adaptation of national policies by involvement in a multi-level process of benchmarking, multilateral surveillance and peer review, exchange of information, co-operation, and consultation. De la Porte, Pochet and Room (2001.:302) conclude in their analysis of the OMC: »The OMC can be characterized as a 'post-regulatory' approach to governance, in which there is a preference for procedures or general standards with wide margins for variation, rather than detailed and non-flexible (legally binding) rules. «By avoiding centralised supranational governance, the OMC shall enable European politics to effectively deal with strong national diversity (see also Commission, 2002). It should therefore help to overcome the institutional obstacles in European social policy: »It could be said that the EES gives up the legal force of traditional regulations in order to allow the EU to deal with some core areas of social policy that were hitherto solely reserved for the Member States « (Mosher and Trubek, 2003.:71).

Thus, the EES is clearly a case of EU soft law, affecting national policies primarily via cognitive influence on dominant national actors. The EES aims to promote full employment through extended coordination. ${ }^{4}$ It favours the modification

\footnotetext{
${ }^{4}$ For a comparison of EES and OECD jobs strategy see Casey, 2004. For a literature review on the EES see de la Porte/ Pochet, 2004.
} 
of governance structures while leaving detailed policy decisions to the national authorities. Though not a European social model in the sense of positive regulation, it might be called a cognitive model or a »framing " policy (see Knill and Lehmkuhl, 1999.): It does not touch the institutional structures of the Member States directly, but promotes certain values (linked to the aim of full employment by means of extended co-ordination), thereby altering the beliefs and expectations of the national actors. Overall, the open method of co-ordination fosters very much cross-national policy learning rather than implementing sanction mechanisms to ensure that the Member States adhere to the EES guidelines (see also Schmid/ Kull, 2004.).

The EES, which is the first coordinated employment strategy developed at EU level, created a new European policy area. This is legally based on the new employment provisions of the Amsterdam Treaty (1997.), Article 126 of which characterises employment as a matter of common concern. However, the traditional national competence for employment policy was maintained. According to the 2002. impact evaluation, the EES has had a major impact on national employment policies of the Member States, which developed in different respects towards the common objectives and the guidelines. ${ }^{5}$ The Commission (2002.) observed that the »comprehensive approach of the EES generally strengthened national employment policy coherence and framework«. It also stated: »The EES also fostered political agreement on new common paradigms, such as lifelong learning and quality in work." Despite such convergence trends, each Member State still focuses on different policies, »and their approaches towards some key issues (e.g. active ageing) seem piecemeal». These results clearly show the limits of the open method of co-ordination that operates without legally binding rules: the $\mathrm{OMC}$ is able to influence the general orientation of national policies, but not their details. However, the EU policy approach produced a new priority for employment objectives in the Member States. In addition, the OMC leads to a restructuring of the domestic policy areas, strengthening co-ordination and involving an increasing number of non-central government-related actors in the employment policy-making process.

In the course of EU enlargement, also the CEE accession states prepared for the appliance of the European Employment Strategy. Although the EES here came in force only after accession, it had to be ensured that the new Member States could take part from the first day on.

The preparations for accession to the EU during the last years increasingly played a role (together with the overall challenges of the transformation situation) in bringing about major changes in CEE employment policies. In particular, the European Social Model emphasises the role of social partners in strengthening sustainable growth, social cohesion, and lifelong learning (to reach the objective of full employment). However, these common influences show different results with regard to the employment policies and labour market institutions adopted (see Riboud et al., 2002). Especially variations in the industrial relations and social dialogue are substantial, both within the new Member States and between them and the old EU countries. ${ }^{6}$

\footnotetext{
${ }^{5}$ For some more details see also Schüttpelz, 2004.

${ }^{6}$ For instance, with respect to the direct collective bargaining coverage, the new Member States are represented at both ends of the scale (with $79 \%$ in Slovenia and $29 \%$ in Lithuania), but most of them are found in the lowest quarter of the ranking of EU countries (European Commission, 2004.:25).
} 
This points to the relevance of differences in national situations, institutions and histories - and in transfer processes. The Czech Republic - in comparison to other CEE accession countries - pursued a rather active employment policy at the beginning of the 1990s. Therefore, the institutional capability of the national policy structure to produce policy change (as a necessary, but not sufficient condition for Europeanisation) could be taken for granted. Also, it has been argued, that the impact of EU policy is higher, when a country is already $\gg$ on the track «, i.e. involved in a process of reform which is consistent with EU trajectories (see Radaelli, 2000a). For these reasons, basic conditions to observe the impact of rather indirect Europeanisation processes, highlighting the role of domestic actors, seem to be given in this case.

THE EUROPEANISATION OF THE CZECH EMPLOYMENT POLICY

The state of the Czech employment policy at the beginning of the preaccession strategy

Until 1997., the Czech Republic was unique among the $\mathrm{CEE}$ countries due to the surprisingly low unemployment it could sustain throughout the transformation process. ${ }^{7}$ However, in the following recession, a lacking demand for labour emerged, and the unemployment rate surpassed $4 \%$ for the first time in Czech transformation history. At this time, the Czech employment policy - like that of other CEE countries was characterised by a residual approach, although (then) Czechoslovakia had quickly developed a quite active and comprehensive employment policy programme at the beginning of the transformation. This had been formally maintained, but politically marginalised and financially subsequently reduced under the neo-liberal Klaus government who considered the labour market as a relatively unimportant policy issue. The Czech government and the Public Employment Services (PES) regarded unemployment as a regional problem caused by the different sectoral structures and developments in the regions during the transformation process. In general, it can be said, that the Czech employment policy developed as a new policy area rapidly at the beginning of the 1990s, but its content and institutional basis were then »frozen « under the Klaus government.

In the Czech Republic, two laws on employment (The Federal Act and Czech Act) passed in 1990. represented the basic legislative framework of employment policy throughout the whole transformation period. The Ministry of Labour and Social Affairs (MLSA), together with the 77 regional labour offices, has been responsible for the organisation and implementation of the employment policy set out in the Employment Act. As a result of the active development of employment services at the beginning of the 1990s, the PES has provided a fairly diverse and modern range of services from the start. These have included information services, brokerage and active labour market policies (training and other measures), as well as the administration of unemployment benefits, and some monitoring of the employers with respect to compliance with the Labour Code. According to the law, advisory boards were established within the labour offices to promote co-operation with employers, trade unions, schools and other relevant actors, but these were used to very different degrees in the respective regions. In general, until 1998 non-state actors played only a marginal role in Czech employment policy, also on the central level. The Social Democratic go-

\footnotetext{
2003.

${ }^{7}$ For a recent analysis of labour market developments in post-communist countries see Casez/ Nesporova,
} 
vernment in place since autumn 1998. then revived the Tripartite Commission (Council of Economic and Social Agreement) originally - as in other transformation countries - established in 1990. Whereas there was practically no dialogue on social reforms, which included the social partners under the Klaus government, a permanent social dialogue was re-established under the new government with the aim of securing social peace. Similarly, private job brokerage and retraining were also part of the Czech employment policy from the beginning, but there was practically no co-operation strategy of the PES towards private actors until the end of the 1990s.

Parallel to these structures, PHAREfinanced institutions (National Training Fund, PALMIF) were established during the 1990s, which managed EU resources to fill the gaps in the supply of state and private employment policies. Although these activities had nearly no quantitative relevance, due to the limited financial support, they helped to establish project management and to test and monitor innovative employment measures in selected pilot regions. In this way, other actors besides the labour offices - like local social partners, training centres, and vocational education schools - also became responsible for employment measures. However, because of the limited competences of the labour offices, which could only implement measures listed in the Employment Act or not financed from state resources, the experiences from the pilot projects were not extended.

To sum up, the effective institutional basis for state employment policies created in 1990. was used very passively under the
Klaus government, and co-operation with other labour market actors was nearly nonexistent.

The adaptation demand of the EU: a broad, but mainly formal approach

Within the framework of the general pre-accession strategy, the European Commission (DG Employment) initiated in 1999 the so called Employment Policy Review, a process of evaluating the labour markets of the accession states with respect to their fitting into existing EU structures and policies. Bilateral Joint Assessment Papers (JAPs) based on the first analysis set out the challenges to be met and the appropriate policies to be implemented. One of the initiators of DG Employment describes the rationale behind the Joint Assessment Papers as follows: »First, the lawyers wentin the framework of the negotiations - also into the administrations of those countries to clarify how to adopt the acquis. And in those areas where there is not this importance of the hard law (these are also other areas), there were then considerations how to structure the preparation process there." (Interview 19, European Commission) ${ }^{8}$ In other words, the Commission aimed to utilise the Employment Policy Review to influence policy-making in the employment area in the candidate countries in the preaccession period. In this context, it is important to keep in mind that the whole JAP exercise is about adopting the acquis, not about problem-oriented policy-making.

The adaptation of the 'acquis communitaire' was the key issue for the EU during the enlargement process (Lendvai, 2004.). The appropriateness of the 'acquis' and its

\footnotetext{
${ }^{8}$ To analyse adaptation to EU policies in the pre-accession period more deeply, I conducted semi-structured expert interviews with Czech and EU actors in the field of employment policy in 2003. The interview quotes throughout this article derive from this fieldwork. The interviews were conducted in English and German. For this article I have translated German quotes into English. Because I guaranteed anonymity to all interview partners, their information are quoted in coded form.
} 
application to the future member states was not questioned. Accordingly, the JAP recommendations concern the necessary steps to finally participate in the EES, not to solve the national labour market problems. However, it can be argued that it could only be by coincidence that the steps to reach both aims would be the same - or (as the implicit EU approach goes) to reach one aim (participating in the EES) would automatically mean to reach the other (solving labour market problems). Nonetheless, during the preparation processes the two aims were frequently mixed up. This reflects the fact that the EU was expected to provide problem-oriented solutions within the framework of enlargement. EU agencies like DG Employment and the European Training Foundation acted as supervisors within the Employment Policy Review setting priorities for the national employment policies of the Accession Countries. However, their approach was rather formal, concentrating on the very existence of labour market reform strategies, whereas the quality of their functioning, i.e. the practical implementation, was rarely touched upon.

The Joint Assessment of Employment Policy Priorities, concluded between DG Employment and MLSA in 2000. as the very first of the accession countries, identifies the following major challenges to be monitored under the Employment Policy Review (JAP, 2000.: 17):

- to maintain appropriate wage developments in line with productivity growth;

- to co-ordinate tax and benefit systems in order to provide greater incentives for people to work and for enterprises to provide employment opportunities;

- to promote occupational and geographical mobility;

- to review the pensions system from an employment perspective;
- to strengthen the public employment service to support a policy shift towards prevention and activation;

- to modernise vocational education and training (VET) in co-operation with the social partners, to make the vocational education system more transparent and focused on the needs of the labour market and, more generally, to adapt the VET system to the demands of a knowledge-based economy and society;

- to strengthen the institutional structures needed to implement the ESF.

The review of the JAPs was mainly a report-writing exercise. As with the enlargement process in general, the Commission was not able to impose sanctions directly upon the accession states, but mainly monitored their progress in fulfilling the agreed obligations. The EU had only two relatively general, but powerful tools to ensure that the policy targets were met: the negotiations and decision regarding accession, and the financial support provided for accession preparations. There was, of course, the perceived necessity of accession states to comply with EU demands to be fully able to profit from future membership. But as employment policy is also a low priority area in the overall EU integration project, the EU's (Commission's) influence in shaping institutional and policy choices was quite diffuse (see also Grabbe, 2002). It was very much limited to legal transposition of the acquis, conducting some PHARE and Twinning activities, monitoring and different forms of policy learning. As a Czech employment policy expert summarises: »The political effect of JAP is zero. It's more a discussion process than political influence.« (Interview 3, National Training Fund)

The progress reports on the implementation of JAPs reflects the low priority given to the fulfilment of the employment agenda set out in these agreements: this is no real 
assessment of the progress made, but just a follow-up of the JAPs describing the state of the employment systems (see Commission, 2003.a and b, and supporting documents). The Commission confirms general progress and focuses on new short-term priorities. One gets the impression that whatever the accession countries did to reform their employment systems was appropriate to reach this next stage, namely concrete preparation for the accession (as shaping the National Development Plans for future ESF funding; work on the National Action Plans; concrete preparation for participation in the EES; and participation of observers in the Employment and ESF Committee). The report just lists the state activities in the different areas and formulates further challenges. In the Czech case, nearly all tasks were still on the agenda at the end of 2003., in particular the reform of the tax and benefit system, pension reform, educational reform and the coordination of actors for participation in EES and ESF. Real integration of accession countries into the EES started in 2003., after the Accession Treaty had been adopted and the review of the EES had been concluded. The Commission and the acceding countries concluded the JAP process with in-depth review seminars held in spring and summer 2003., which should allow for the preparation of the first $\mathrm{Na}$ tional Action Plans (to be presented within the new EES in October 2004.). At the same time, the acceding countries joined the »Employment Incentives Measures « programme (the peer review network within the EES) as well as the Employment Committee and the ESF Committee (until accession as observers).

\section{Reforms of the Czech employment policy during the pre-accession strategy}

However, during the pre-accession stage (1997.-2004.), the Czech Republic was quite active in reforming its employment policy. These reforms were prompted by the currency crisis and subsequent recession in 1997., which set the Klaus government under mounting pressure. The government responded initially by implementing a strict austerity program that slowed down government spending (see CERGE-EI 2003.). The recession shattered the illusion of the »Czech miracle«, a successful transformation without mass unemployment. This contributed to the fall of the right-wing coalition headed by Vaclav Klaus' Civic Democrats, who had been in power since 1992. (although Klaus had actually resigned over party finance scandals).

In face of the ongoing recession, the new Social Democratic government revived structural reform and privatisation and introduced an aggressive FDI incentive package. In its policy statement of August 1998., the government focused on reviving economic growth by applying active industrial, agricultural, and pro-export policies. The Social Democrats also declared that they would adopt the Social Charter of the Council of Europe, one of the five priorities set by the new government.

The Czech government's »Economic strategy of the accession to the European Union« of May 1999. thus included a wide range of policies to achieve a sustainable increase in competitiveness and employment. Nevertheless, the Czech economy continued to decline in 1998. and 1999., and unemployment increased to $9 \%$. In this situation, the MLSA launched a new approach to the employment policy based on the Social Democratic electoral programme, the Accession Partnership and the EES. Fully in line with the economic strategy mentioned above, the National Employment Plan (NEP), a medium-term strategy developed in 1999., states that employment policy should become $»$ an integral part of overall economic, regional, social and educational 
government policies « (MLSA 1999.). A reallocation of resources towards active labour market policies was considered necessary. As an expert of the Czech Confederation of Trade Unions summarises these employment policy trends: »Between 1990. and 1999. the prevailing rightwing thinking meant that employment policy and labour markets was seen as a sphere of competitive market forces - no special attention was given to it. This was also connected to the fact that the employment situation was not so bad until 1996., with unemployment under $5 \%$. The situation changed because the elections in 1998. resulted in a more or less social-democratic government. Therefore, the attention to social and employment policy was higher. In addition, we came closer to the EU. This made some rhetoric difference in programmes - the ODS and rights support market forces, no state - but also in financial practice." (Interview 7, ČMKOS)

Concerning the financial practice, the numbers really show a change in the general orientation of the Czech employment policy: Whereas the proportion of expenses for the active employment policy to total employment policy costs was only $14 \%$ in 1997., it grew up to $44 \%$ in 2002. (see Potůček, 2004.). This is a first sign that the programme's changes have not been just rhetoric. But the new approach comprised more than policy integration and financial reallocation. One of its basic objectives was activation, representing a shift of responsibility away from the state towards the unemployed and employed, the social partners, NGOs and other social actors. As the NEP puts it: »New labour market realities call for a new definition of objectives, means of employment policies and actors shaping further development. It is necessary to transfer the focus, as well as financial flows, from the 'mere' material security, which maintains people in waiting passively (relying on benefits) towards the provision of incentives to change the status quo. The National Employment Plan gives a clear preference to creation of new jobs, improvement of employability, increased flexibility of workers and, on the other hand, discourages reliance on the social safety net (MLSA 1999.).

Another key objective of the new employment policy approach was to improve the matching of labour demand and supply, in particular with respect to qualifications. Moreover, it referred actively to the EU accession process and respective policy implementation. It dealt with the transfer of the EU acquis and put special emphasis on the EES. The EU employment policy guidelines were understood to focus on measures for employment creation and on prevention of social exclusion. The National employment plan adopted these EU objectives and oriented its measures towards the EES priorities. The MLSA thereby relied on the EU employment guidelines and the national action plans of the Member States. In sum, the new Czech approach included not only an activation of the employment policy, but also full harmonisation of the policies and legislation in the area of employment with the acquis. All proposed measures complied with the respective EU employment guidelines. However, some differences between the Czech policy approach and the EES remained. On the one hand, in particular co-operation with social partners and local labour market actors was not so well developed in the Czech Republic. On the other hand, the Czech government put a special emphasis on the question of foreign labour and undeclared work, as well as on investment and industrial programmes.

Since 2001., this NEP mid-term strategy was refined and further developed through yearly National Action Plans of Employment, which took into consideration the latest developments in the EU guidelines. These policies included among others preventive and concrete employability-oriented 
measures, improved co-operation with the regional level, attempted to reduce the tax burden of labour, as well as activities to facilitate return to the labour market and policies to support families - all measures that were not yet dealt with in 1999. Also, the Czech Government as a priority launched the policy of equal opportunities in 2001., and the method of mainstreaming was applied.

Since 1999., under the main responsibility of the Ministry for Regional Development, the National Development Plan, the basic strategic document for receiving support from the Structural Funds and the Cohesion Fund, was also prepared in the Czech Republic. In this context, the $\mathrm{Hu}-$ man Resource Development Operational Programme (HRD OP) was produced by MLSA in 2002. in its final version. This programme is the basis for co-financing measures in the area of HRD from the European Social Fund (ESF). As a result, a systematic development of the adult training system has been approached in the Czech Republic since 2001.

All these and other documents developed in the context of the pre-accession strategy (as the JAP and the National programme for the development of education in the Czech Republic) share one basic feature: for the first time a coordinated employment policy is approached in the Czech Republic. This means the development of policies and programmes had been coordinated between actors on the central and the regional level at the one hand, and between various central actors on the other hand. Therefore, the new employment policy approach concerns not only the scope and content of the developed policies, but also a decentralisation, i.e. a certain shift of competencies and responsibilities away from the ministry (which nevertheless, remains the central actor). This is also in line with the requirements of the EES, which is above all about coordination. However, there remain certain problems with the implementation of this coordinated approach. As the Commission formulates in its updated progress report on the implementation of the JAP in the accession countries: »Substantial efforts are needed to move towards a more coordinated design and implementation of employment policies, to up-grade the administrative capacity for policy planning and delivery, and to promote the participation of the social partners. There are also concerns about the financial and administrative resources needed to ensure full use of the Structural Funds and of the ESF in particular« (Commission, 2003: 2).

In developing these policies, the Czech Republic (and other accession countries) not only referred to the relevant EU documents and the recommendations and regular comments from the European Commission, but also to the experiences of the Member States. As the ex-ante evaluation of the HRD OP states, these strategies »are the first documents of this kind in the Czech Republic. It was impossible to build on previous experience, and it was therefore very important to use the experience of the EU member countries « (National Observatory 2003.:12). The organisations involved into the development of these strategic documents often enjoyed technical assistance from EU country experts. The PHARE Twinning programme initiated in 1998. is one of the European Union's pre-accession instruments specifically designed to provide such assistance. With 15 twinning projects started by 2002. (some as early as 1999.), the Czech Republic has been by far the most active accession country using Twinning experts in the fields of employment and social affairs (see European Commission, 2003.). The MLSA initiated for instance projects to develop the social dialogue, equal opportunities, the preparations for the ESF, the coordination of social security within the EU, occupational safety and health, and social inclusion. 
The rationale behind the supervision and consulting the twinners exercised within the project was described by a Swedish expert as follows: »Officially, I'm a European representative, but when a [candidate] country chooses a project, they choose countries, they have a perspective, what the countries do in a certain area. I cannot renounce the Swedish perspective. This is an official EU policy, but according to my experience we disseminate best practices." (Interview 18, Twinning) That is, the knowledge provided about the EU policies and institutions by the twinners is always bound to their national perspective - and this special perspective on the implementation of certain EU policies is intended and does matter for the policy transfer. So, what is transferred under these circumstances is not a »pure « EU policy, but a certain national interpretation of this policy. Often there is a clear concentration on special knowledge: In the Czech Republic all projects on ESF and on social inclusion between 1998 and 2002 were carried out by British twinning partners, whereas Swedish partners provided their competencies in the field of equal treatment, and Danish on the improvement of Social Dialogue. This illustrates the puzzling character of the policy transfer in the pre-accession context.

Overall, the labour market reforms in the pre-accession period concern mainly the first five priorities of the JAP (see above). The Czech Republic activated its labour market policy, including new measures to promote mobility of the labour force and targeting at long-term unemployed. From 1999. on, Social Democratic governments implemented a continuous rise of the minimum wage, and the income tax was reformed. Early retirement was made less attractive, starting in 2001., and the employment rates for elderly improved. The Czech Republic also reduced regulative and administrative burdens to promote SMEs, and increased the flexibility in contractual agreements (in particular with the 2000 . amendment of the Labour Code and the respective transposition of EU labour law directives). A legal and institutional framework for gender equality policies has been established from the change in government in 1998. onwards. The broader reform of the social security system was approached from 2003. on.

\section{Limited Europeanisation of policy structures prior to accession}

In these reform processes, the structural integration of various actors in the employment policy area was also improved. The government promoted a social pact, and actively involved the regions, social partners, local authorities, and other interested groups in the policymaking. In fact, a key feature of the Czech labour market reforms from 1998. through 2003. is the powerful role the trade unions play in influencing the government and the Parliament (see Jurajda and Mathernová, 2004.) in several policy and institutional dimensions. ${ }^{9}$ The social dialogue under the Social Democratic government has been extended and institutionalized beyond the tripartite meetings: »The government organizes so-called »social conferences « which are attended by representatives of the trade unions, employer associations, associations of pensioners, think tanks, etc. These conferences discuss forthcoming legislation. Another illustration are the »round-table« meetings

\footnotetext{
${ }^{9}$ The close proximity between the trade unions and the Social Democrats is demonstrated by the fact that functionaries of the trade unions are elected to the Parliament on the ballot of the Social Democrats, many governmental advisors are also former associates of the trade union movement, and the current Minister of Labour and one of his deputies are former officials of the trade unions.
} 
of powerful parliamentary committees with the social partners. (Jurajda and Mathernová, 2004.:26)

However, the adaptation to the EES led only indirectly, and thus lately, to some new institutions in the area of employment policy. For example, in spring 2003., the Czech government adopted a national strategy for human resource development and established national and regional councils for HRD with representatives of state administration, regional governments, and social partners which coordinate employment, vocational education and training, qualification and entrepreneurship issues (see Cedefop Info No 3/2003.). In principle, the Ministry of Labour and Social Affairs (MLSA) has remained the most powerful actor in decision making on employment issues during the pre-accession period, but acquired additional responsibilities, e.g. with the preparation for the ESF and management of the related programmes (OP-HRD). Trade unions and employers' associations participating in the central tripartite Council of Economic and Social Agreement have been re-established as its most relevant partners. In addition, the Social Democratic-led MLSA introduced new forms of communication with relevant labour market actors. Representatives of NGOs, experts, and civil servants discuss important issues before the Ministry and/or government takes the final decision.

Nevertheless, programming and implementation of the National Action Plans since 1999. markedly contributed to change the practice of employment politics in the Czech Republic. From the beginning, apart from employment services, also other actors, in particular the ministries of education, industry, regional development and the interior, were involved in the implementation of the new employment policies. Later on, the ministries, social partners, and other actors also participated in the development of the yearly plans. In 2002., in such a co-operation for the first time performance indicators have been prepared - similar to those used by EU member states - in order to evaluate the policy implementation (see National Observatory of Employment and Training, 2002.). As the implementation of the new employment policy was severely hampered by a lack of resources, the preparations for participation in the ESF gained increasing importance, which also contributed to a wider co-operation of different employment policy actors. Similarly, at the regional level, the co-operation between labour offices, state authorities, social partners, development agencies and others in planning the regional employment policies developed over time.

There has been increasing EU assistance in institution and capacity building (e.g. PHARE projects) in the development of the instruments of labour-market policy, in the reform of social services, in the development of policies on human rights and equal opportunities, and in collaboration in the field of education (see Potůček, 2004.). Specifically designed projects were launched to assist the reform of public administration, regulatory reform, training of professionals (including civil servants), and implementation of new methods of public management and administration. These were the most significant financial instruments used during the accession period to provide social policy advice to the CEE countries aiming at reforms in this policy sector. However, the projects and support focused very much on the adoption of the 'acquis' and the development of institutional capacities to deal with EU policies after accession, but did not directly contribute to basic reforms, which could be necessary for a successful employment policy in the transformation countries.

\section{CONCLUSION}

The EU has been influential on procedures, as well as on content of the Czech 
employment policy during the pre-accession period, although in rather indirect ways. Above all, EU programmes have been able to reinforce institutional capabilities and new modes of governance in the policy area. In particular, the future participation in the ESF provided concrete financial incentives to the domestic actors in the government and ministries to develop respective institutional structures and co-operation. However, under the pre-accession conditionality regime, the EU also acted successfully as an agenda-setter in the Czech employment policy by setting (and financing) reform priorities. This Europeanisation of policies mainly worked, because domestic actors, in particular at the MLSA, could make use of the EU policies to pursue their own aims concerning a reform of the national employment policy. Therefore, the EU policies increasingly influenced domestic debates and policies, as in the fields of gender equality, anti-discrimination policies, and the fight against social exclusion (see also Guillén/ Palier, 2004.).

The JAP was a necessary precondition for this type of EU influence, as it clarified the expectations of the EU with respect to the labour market reforms of the accession countries, at least to some degree. However, the requirements stemming from the EU soft law continued to be rather unspecific in comparison to hard law adaptation, as the Commission did not act as a »pushing agent $«$ to promote actively the EES in the accession countries. Neither in the general Progress Reports nor in the assessments of the JAP can any serious effort to promote »Social Europe « and to approach full employment be seen. Therefore, the EU policy influence in this policy area remained structurally weak. In the Czech case, the new Social Democratic government, and in particular the MLSA, promoted EU accession in general, and used the EES actively as a model for policy reforms - in other words, they acted as »pulling agents « for an employment policy transfer. This was less due to adaptation pressure from the EU or formal necessity (as the Czech Republic performs quite well in terms of common EES indicators, see also Walewski, 2003.), but rather to the perceived reform pressure stemming from sharply raising unemployment and the new policy orientation after the change in government. The dominant Czech policymakers in this situation perceived and reinterpreted the ambiguous EU ideas about labour market reforms as a chance to activate the employment policy and to improve coordination among the relevant actors in the field. In addition, the (anticipated) possibility to receive additional financial means from the EU pre-accession programmes, but especially from the ESF (after accession) was crucial to develop mid- and long-term strategies, new policies, and structures that fulfil the EU conditions for co-funding of projects. These instruments especially promoted co-operation, exchange, active policy development, and institution building. The structural result is a certain decentralisation of the Czech employment policy.

Thus, the development of employment policy in the Czech Republic depended less on adaptive pressure stemming from institutional misfit and/or enforcement of concrete policies in this field by the EU, but on adaptive pressure concerning administrative structures and on the necessity to improve the »institutional capacity«. One may say, concerning policy development, Europeanisation in this policy area was more »national-driven «, and more »EUdriven « concerning institution building.

Concerning the EES, the employment policy review, explicitly designed to foster Europeanisation in the pre-accession situation, has been only one way to adapt the Czech employment policy to the EU model. The National action plans, based on a mid-term strategy that shares explicitly 
the central ideas of the EES, are the result of another policy transfer process not directly linked to the employment policy review. These plans have been increasingly oriented towards the Employment Guidelines by putting more and more emphasis on HRD, a comprehensive and efficient active labour market policy, as well as an adequately equipped Public Employment Service. They shaped the Czech employment policy significantly during the preaccession period. Although all strategic documents are formally in line with the JAP, they set own priorities, sometimes different from those identified under the employment policy review. As a Czech employment policy expert puts it: »There are no conflicts, but problems with some recommendations, because it is not so easy to implement them. For instance a better balance between social security benefits and minimum wages: Currently, it doesn't encourage people to take training and so on. But there is especially no political will to decrease social benefits. It's not so easy to implement. In addition, taxation of labour is relatively high. But because of our budget problems it's not possible to decrease it." (Interview 10, MLSA)

In general, the employment policy reforms in the pre-accession period focussed very much on the harmonisation with EU labour and social law, organisational preparation for the ESF, and a general reorientation of the employment policy. However, these Europeanisation processes followed different implementation logics. Areas expected to have high benefits (transposition of EU regulation as absolute necessity for accession, preparation for participation in ESF) had been given higher priority than the adaptation to the EU's »soft law« throughout the pre-accession period (see also Grabbe, 2002.). What is at first sight somewhat surprising is, that in the Czech Republic the EES has also played a significant role in framing the employment poli- cy agenda. The EES and the Employment Policy Review as the concrete EU strategy to transfer EU employment policy aims to the accession countries did not create any major adaptional pressure on their own, despite the existing institutional misfit (giving the rather residual employment policy in the Czech Republic at the beginning of the pre-accession stage). The EES was not presented as a EU norm explicitly to follow before accession, and the Employment Policy Review was dealt with as a pure formal procedure to be followed by both sides, the Commission and the involved experts in the MLSA. However, the Employment Policy Review contributed to increase attention for EU employment policy aims within the MLSA, to promote regular exchange of ideas with the Commission, and to familiarise national experts with EU monitoring procedures. A unit for European integration was established within the MLSA. Thus, there were some small changes brought about with the Employment Policy Review.

But although the EES did not create major adaptional pressure in the institutional sense that accession countries had to comply with EU employment norms (because they had not to prior to accession), it triggered Europeanisation via cognitive and structural mechanisms. In the situation of sharply rising unemployment and a change in government in 1998, there was a demand to develop a new approach to the employment policy. The EU explicitly served as a welcome model to this reorientation and was therefore voluntarily transferred respectively used as a kind of blueprint to develop national employment strategies. The interest of Czech governmental officials, especially the MLSA, to use the European Employment Strategy as an inspiration for building up a new national employment strategy led to a quite early adaptation of programmes to the EES. The overall aims, structures, and policies from the EU employment guidelines were adopted which 
has led to a number of new measures, legislative initiatives, and co-operation in the policy field. The programmes increasingly favoured activation concepts and inter-organisational co-ordination, and integrating education and training with the labour market is now high on the agenda. The Czech Republic also was the first accession country to sign the JAP (in 2000.). Thus, we can see three factors influencing the »voluntary « adaptation to a soft EU policy: the nature of the socio-economic problem to deal with (namely growing unemployment), the political situation (new Social Democratic government), and external influences (the approached accession to the EU).

The coercive pressures for Europeanisation increased over time. This can be illustrated by the adoption of the NEP and the HRD OP, respectively. Whereas the agency for policy transfer stood clearly on the pull side in the first case, when the MLSA (more or less) voluntarily decided to draw a lesson from the EES, Member States no longer have the choice to rely on EU regulation or not. Instead, they start to participate in standard EU procedures (as the OMC) and are directly exposed to EU rules. In the case of the HRD OP this means that the European Commission was clearly acting as a pushing agent by constantly demanding the submission of the plans, providing technical support for the preparation, and commenting and assessing extensively the respective drafts. Moreover, non-compliance would have serious financial consequences. Also, the EES has undergone significant change since 1998. - first with the acceptance of specific objectives for 2010. and 2005. at Lisbon and Stockholm 2000., then with the updated strategy of 2003. (the EU as a »moving target « for the accession countries). These changes meant a need for more concrete and coordinated policies to the old as well as to the new Member States. Thus, the pressure to adopt increased even in a double sense at the eve of accession.
In addition, the anticipated financial consequences from following the EES - namely co-financing of employment measures from the ESF after accession - made it increasingly rational to adopt the EES as accession approached. The EU did condition financial help in the pre-accession period to reforms aiming at the adoption of the aquis according to the priorities set under the Accession Partnerships. In the field of employment policy this concerned above all the harmonisation of labour law and the institution building and programming for future participation in the ESF. As the ESF is designed as the financial instrument of the EES, there was also a kind of indirect conditionality to adopt the EES. This lead to a concretisation of employment programmes, implementation of pilot projects and promoted very much the establishment of new co-operation structures in the field as accession approached. However, at the time of accession, the approach still was not systematic enough and the implementation of these programmes faced severe problems. Thus, practical results of the policy reorientation were rather limited up till that time.

All in all, the EES and the Employment Policy Review - as the interpretation of the Commission for adaptation demand arising from the EES in the framework of the preaccession strategy - worked very much as »framing policies « as they fostered mimetic adaptation and policy learning in the Czech case. Nevertheless, the adaptation was not a completely voluntary decision of Czech policymakers (in the MLSA and government), but was indirectly reinforced by the EU. Although the Commission did not actively initiate or demand the adoption of the EES during the pre-accession period, it promoted the activities of the Czech Republic by providing financial and technical assistance (PHARE and Twinning) as well as by monitoring the preparations for accession. In this way, the EU was influential more directly on procedures than on contents of 
the employment policy which may have rather long-lasting effects, in particular as the new Member States have been fully involved in the EES since accession. In any case, the Commission has not the power to push through compliance with soft law, so the adaptation to the EES works rather as active reinforcement from both sides - the EU and the Member States.

Overall, a considerable Europeanisation of the Czech (and others) employment policy took place in the pre-accession period. However, the respective preparation processes differed, and certain transfers have had a more voluntary character than others. For example: The employment policy review (JAP process) established a range of obligations, but without serious control mechanisms and consequences, and the drawing up of the national action plans may be even characterised as a rather voluntary learning process. As a Czech employment policy expert puts it: »The JAP was just joined, you can't avoid it. But the European guidelines have been a source already from the beginning - we have the same structure and a similar process. Besides: Why develop another process when sooner or later we have to join in anyway? So far, we are not forced to do it, but we have time to learn the process and how to involve different partners in the process. "(Interview 11, RILSA) However, this perception of voluntariness, which is quite widespread among employment policy actors in the Czech Republic, is certainly owned largely to the framing character of the EES. This is, why a representative of the Delegation of the European Commission in Prague comments rather sceptical on the success of this Europeanisation in the pre-accession period: »There are now the action plans, the Joint Assessment and reports on it, where you can find different strategic points stemming from $\mathrm{Eu}$ ropean employment strategy. But - and this is my personal view - there is a wide gap to reality, wider as in the Member states, where there is also one thing at paper and some difference in practice. These papers are mainly to satisfy the European Commission. Once we are Members, you will see, some things are not well implemented, for instance more flexibility in the labour market, movement of labour force - because to do so would imply much higher social costs, because of the transformation situation." (Interview 13, European Commission)

Nevertheless, it has to be considered that the EU was quite successful in setting the employment policy agenda under the Czech conditions, and the Czech employment policy was subsequently streamlined to an EES approach during the pre-accession period. It is increasingly focusing on labour market policy regulation, as well as the prevention and activation concepts and paradigms such as lifelong learning. The modernisation of the vocational education and training has been approached, and the government is promoting flexible work contracts. This means a clear strategic convergence towards the EU policy. There is also some evidence of a greater awareness regarding the need for co-operation and information exchange in the employment policy among officials. However, as within the EU, there is a certain gap between strategic changes and implementation. The Public Employment Service is reoriented towards prevention, activation, and individual approach - but whether this helps in addressing the growing unemployment problem has to be subject of further evaluation. In fact, the problems of the Czech employment policy may well be less due to existing institutional structures than to a lack of financial resources and lower economic performance than in the old Member States.

\section{REFERENCES}

Ardy, B. and Umbach, G. (2004.) Employment policies in Germany and the United Kingdom: The impact of Europeanisation. London: Anglo-German Foundation. 
Börzel, T. (1999.) Towards convergence in Europe? Institutional adaptation to Europeanization in Germany and Spain. Journal of Common Market Studies, 39(4):573-596.

Börzel, T., and A. R. Thomas, (2005.) Conceptualizing the Domestic Impact of Europe. In: K. Featherstone and C. Radaelli (eds.), The Politics of Europeanisation (pp. 57-80). Oxford: Oxford University Press.

Casey, B. H. (2004.) The OECD Jobs Strategy and the European Employment Strategy: Two Views of the Labour Market and the Welfare State. European Journal of Industrial Relations, 10(3):329-352.

Casez, S. and Nesporova, A. (2003.) Labour Markets in Transition: Balancing flexibility and security in Central and Eastern Europe. Geneva: ILO

CedefopInfo No 3/2003. Retrieved from the http:// www2.trainingvillage.gr/download/Cinfo/ Cinfo32003/C33D3EN.html

CERGE-EI (2003.) Czech Republic 2002. Invited to the EU. Prague: Center for Economic Research and Graduate Education (see also www. cerge-ei.cz)

Commission of the European Communities (2002.) Communication from the Commission to the Council, the European Parliament, the Economic and Social Committee and the Committee of the Regions. Taking Stock of Five Years of the European Employment Strategy. Brussels, COM 416 final.

Commission of the European Communities (2003. a) Communication from the Commission to the Council, the European Parliament, the European Economic and Social Committee and the Committee of the Regions. Progress on the Implementation of the Joint Assessment Papers on Employment Policies in Candidate Countries. Brussels, COM 37 final.

Commission of the European Communities (2003. b) Communication from the Commission to the Council, the European Parliament, the European Economic and Social Committee and the Committee of the Regions. Progress in Implementing the Joint Assessment Papers on Employment Policies in Acceding Countries. Brussels, COM 663 final. Document available at:http://europa. eu.int/comm/employment_social/employment_ analysis/communi2_en.htm)

De la Porte, C. and Pochet, P. (2004.). The European Employment Strategy: Existing Research and Remaining Questions. Journal of European Social Policy, 14(1):71-78.

De la Porte, C. and Pochet, P. and Room, G. (2001.) Social Benchmarking, Policy Making and New
Governance in the EU. Journal of European Social Policy, 11(4):291-307.

Dolowitz, D. P. and Marsh, D. (2000.) Learning from Abroad: The Role of Policy Transfer in Contemporary Policy-making. Governance, 13(1):5-24.

European Commission (2003.) Institution Building. Twinning projects under PHARE 1998.-2002. Bruxeless: Directorate-General Enlargement.

European Commission (2004.) The social situation in the European Union 2004. Retrieved September 20 2005. from the Eurostat Web site: http://epp. eurostat.cec.eu.int/cache/ITY_OFFPUB/KE-AG04-001/EN/KE-AG-04-001- EN.PDF

Falkner, G. and Treib, O. and Hartlapp, M. and Leiber, S. (2005.) Complying with Europe. EU Harmonisation and Soft Law in the Member States. Cambridge: Cambridge University Press.

Goetschy, J. (1999.) The European Employment Strategy: Genesis and Development. European Journal of Industrial Relations, 5(2):117-137.

Grabbe, H. (2002.) European Union Conditionality and the Acquis Communautaire. International Political Science Review, 23(3):249-268.

Green C. M., Caporaso, J. and Thomas R. (eds.) (2000.) Transforming Europe: Europeanization and Domestic Change. Ithaca and London: Cornell University Press.

Guillén, A. M. and Palier, B. (2004.) Introduction: Does Europe matter? Accession to EU and social policy developments in recent and new member states. Journal of European Social Policy, 14(3):203-209.

Héritier, A. and Knill, C. (2000.) Differential responses to European policies: a comparison. Bonn: Max Planck Projektgruppe Recht der Gemeinschaftsgüter, preprint.

Jacquot, S. and Cornelia W. (2003.) Usage of European Integration. Europeanisation from the Perspective of Political Sociology. A paper prepared for the ECPR General Conference 2003.

Joint Assessment of Employment Policy Priorities of the Czech Republic (2000.) All JAPs can be retrieved from the EU web pages:http://europa. eu.int/comm/employment_social/employment analysis/japs_en.htm.

Jurajda, Š. and Katarína M. (2004.) How to Overhaul the Labor Market: Political Economy of Recent Czech and Slovak Reforms. A background paper prepared for the World Development Report 2005 ..

Knill, C. and Dirk L. (1999.) How Europe matters: different mechanisms of Europeanization. European Integration online Papers (EIoP), 3(7). 
Retrieved June 29, 2005 from the European Integration Online portal: http://eiop.or.at/eiop/ texte/1999-007a.htm.

Lendvai, N. (2004.) The weakest link? EU accession and enlargement: dialoguing EU and post-communist social policy. Journal of European Social Policy, 14(3):319-333.

Ministry of Labour and Social Affairs (MLSA) (1999.) National Employment Plan. Available at www.mpsv.cz.

Ministry of Labour and Social Affairs (MLSA) (2002.) Czech Republic National Action Plan for Employment 2002. NEAP approved by Government Resolution No. 249/2002.

Mosher, J. S. and Trubek, D. M. (2003.)Alternative Approaches to Governance in the EU: EU Social Policy and the European Employment Strategy. Journal of Common Market Studies, 41 (1):63-88.

National Observatory of Employment and Training (2002.) Short Country Report on Recent Developments in Education, Training and Employment Policy. Czech Republic. Retrieved from the Czech National Training Fund Web site: http://www.nvf. cz/observatory/dokumenty/publikace/eng/short country_report.pdf.

National Observatory of Employment and Training (2003.) Ex-ante Evaluation of the Human Resources Operational Programme. Prague.

Potůček, M. (2004.) Accession and social policy: the case of the Czech Republic. Journal of European Social Policy, 14(3):253-266.

Radaelli, C. M. (2000.a) Whither Europeanization? Concept stretching and substantive change. $E u$ ropean Integration online Papers (EIoP), 4(8). Retrieved June 16, 2005 from the European Integration Online portal: http://eiop.or.at/eiop/ texte/2000-008a.htm.

Radaelli, C. M. (2000.b) Policy transfer in the European Union. Governance, 13(1): 25-43.

Radaelli, C. M. (2004.) Europeanisation: Solution or problem? European Integration online Papers (EIoP), 8(16). Retrieved June 29, 2005 from the European Integration Online portal: http://eiop. or.at/eiop/texte/2004-016a.htm
Riboud, M. and Carolina S. P. and Carlos S. J. (2002.) Does Eurosclerosis Matter? Institutional Reform and Labor Market Performance in Central and Eastern European Countries. In: F., Bernard and P. Lodovico (eds.): Labor, Employment, and Social Policies in the EU Enlargement Process: Changing Perspectives and Policy Options (pp.243311). Washington, D.C.: The World Bank, Retrieved September 20, 2005 from the World Bank web site: http://www-wds.worldbank.org.

Scharpf, F. (1997.) Economic Integration, Democracy and the Welfare State. Journal of European Public Policy, 4(1):18-36.

Schimmelfennig, F. and Ulrich S. (2002.) Theorizing EU Enlargement: Research Focus, Hypotheses, and the State of Research. Journal of European Public Policy, 9(4):500-28.

Schimmelfennig, F. and Ulrich S. (eds.) (2005.) The Europeanization of Central and Eastern Europe. Ithaca: Cornell University Press.

Schmid, G. and Silke K. (2004.) Die Europäische Beschäftigungsstrategie. Anmerkungen zur $\gg$ Methode der offenen Koordinierung «. WZB Discussion Paper SP I 2004.-103. Berlin: Wissenschaftszentrum Berlin für Sozialforschung.

Schüttpelz, A. (2004.) Policy Transfer and Pre-accession Europeanisation of the Czech Employment Policy Discussion Paper SP III 2004.-201. Berlin: Wissenschaftszentrum Berlin für Sozialforschung.

Vink, M. (2003.) What is Europeanisation? And other Questions on a New Research Agenda. European Political Science, 3(1):63-74. Retrieved June 16, 2005. from the European Consortium for Political Research Web pages: http://www.essex.ac.uk/ ecpr/publications/eps/onlineissues/autumn2003/ research/vink.htm.

Walewski, M. (2003.) European Employment Strategy - a Policy for Visegrad Countries? Assessment of the V4 labour markets given the objectives and priorities of the reformed EES. In: A. Joanna. and M. Kaniewska and M. Sitek and M. Walewski and K. Szczygielski (eds.), Policy Makers or Policy Takers? Visegrad Countries Joining the EU-Selected Studies (pp. 57-82.). Warsaw: Center for Social and Economic Research (CASE). 


\title{
Sažetak \\ EUROPEIZACIJA POLITIKE ZAPOŠLJAVANJA U REPUBLICI ČEŠKOJ
}

\author{
Anne Schüttpelz \\ Centrum für Globalisierung und Governance \\ Department für Wirtschafts und Sozialwissenschaften, Universität Hamburg \\ Hamburg, Germany
}

Iako se Europska strategija zapošljavanja (EES) primjenjuje na nove države članice tek nakon njihova pridruživanja, ona je oblikovala češku politiku zapošljavanja davno prije toga. Stoga se postavlja pitanje kako je EES mogla zadobiti takav utjecaj, usprkos činjenici da ne predstavlja niti posebno snažnu vrstu europske regulative, niti ju je nametala Europska komisija u okviru svoje predpristupne strategije. Teorija europeizacije sugerira da temeljno institucionalno neslaganje između propisa Europske unije i nacionalnih propisa, kao i određeni nacionalni uvjeti, mogu objasniti prilagodbu nacionalnih politika normama Europske unije.

Ipak, kako je Europska strategija zapošljavanja mekša vrsta propisa Europske unije, kognitivni utjecaj na dominantne nacionalne aktere igra važnu ulogu u njezinom djelovanju. U češkom slučaju, Europska je unija s priličnim uspjehom utjecala na postavljanje prioriteta u zapošljavanju - interpretaciju problema tržišta rada oblikovali su ciljevi Europske strategije zapošljavanja, što je dovelo do aktivacije i povećanja učinkovitosti politike zapošljavanja. No uzorno funkcioniranje Europske strategije zapošljavanja bilo je presudno za uspješnu i ranu prilagodbu u većoj mjeri nego prikaz službene politike zapošljavanja kao dio predpristupne strategije.

Ključne riječi: Europska strategija zapošljavanja, Republika Češka, prilagodba, pridruživanje Europskoj uniji. 


\title{
FRIEDRICH

International Conference on

\section{SOCIAL POLICY AND REGIONAL DEVELOPMENT}

\author{
30 November 2006, Zagreb, Croatia
}

The Institute of Economics, Zagreb and Friedrich Ebert Stiftung, Croatia organize this international conference and invite all interested to participate in the conference.

Social policy and regional development are often narrowly defined and treated as separate and distinct areas of scientific study. Indeed, in the context of transition and prospective membership of the European Union, reforms in each are considered necessary and are the subject of scientific and political debate in Croatia as in many other countries.

This conference aims to bring the topics together and to explore aspects of territorial cohesion, social inclusion and social justice. It will focus on the regional (sub-national) dimensions of social policy, and the social dimensions of regional development policy. International key note speakers and paper givers will be drawn from social sciences, in particular from economics, social policy, sociology and planning.

\section{IMPORTANT DATES}

Abstract submission deadline: by $15^{\text {th }}$ May 2006 - CLOSED Abstract acceptance notification: by $31^{\text {st }}$ May 2006

Full Paper submission deadline: by $15^{\text {th }}$ September 2006 Full Paper acceptance notification: by 15 October 2006

Registration - other participants: by 15 November 2006

CONTACT \& INFORMATION

Conference information, web-site: $w w w . e i z g . h r$ Conference E-mail: conference@eizg.hr

dr. sc. Marijana Sumpor, Conference coordinator

The Institute of Economics, Zagreb

Trg J. F. Kennedya 7, 10000 Zagreb, Croatia Phone: +385 (0)1 2335 700; Fax: +385 (0)1 2335 165;

The Institute of Economics, Zagreb - EIZ web-site: www.eizg.hr Friedrich Ebert Stiftung, Croatia - FES web-site: www.fes.hr 